\title{
Effective removal of chemical oxygen demand and phosphates from aqueous medium using entrapped activated carbon in alginate
}

\begin{abstract}
The aim of this study is to decrease different wastewater contaminants using entrapped activated carbon in alginate polymer (AG-AC) by adsorption. Different phosphate concentrations were prepared in the laboratory. The effect of the operating parameter was studied by external factors (e.g., contact time, $\mathrm{pH}$, concentrations, adsorbent dose, and stirring rate). The results were analyzed according to the Freundlich and Langmuir adsorption isotherm. The adsorption data are more appropriate by the Freundlich isotherm. Efficient removal percentages for $\mathrm{COD}(500 \mathrm{mg} \backslash \mathrm{L})$ at $\mathrm{pH} 3$ using dose $30 \mathrm{~g}$ of the adsorbent for $60 \mathrm{~min}$ with a fixed stirring rate at $100 \mathrm{rpm}$ were about $(79 \%)$. Efficient removal percentages for phosphates $(5 \mathrm{mg} \backslash \mathrm{L})$ at $\mathrm{pH} 4$ using dose $30 \mathrm{~g}$ of the adsorbent for $45 \mathrm{~min}$ with a fixed stirring rate at $100 \mathrm{rpm}$ were about $(89 \%)$. The best-operating conditions have been determined to increase phosphate removal efficiency.
\end{abstract}

Volume 3 Issue 6 - 2018

\author{
Soha A Abd El-Gawad,' Hossam M Abd El- \\ $\mathrm{Aziz}^{2}$ \\ 'Chemistry Department, Faculty of Science, Cairo University, \\ Egypt \\ ${ }^{2}$ Chemical Industries Development (CID) Company, Egypt
}

Correspondence: Hossam Mohammed Abd El Aziz, CID Company, Giza, Egypt, Tel 00201229102427,

Emailhossam_elywa@yahoo.com

Received: August 08, 2018| Published: December 28, 2018

Keywords: entrapped AG-AC, COD, phosphate, adsorption study

\section{Introduction}

Water is the basis of life on the Earth and the most important natural resources after air for all living organisms. During the natural cycle of water, humans capture and divert a lot of the water, it returned to the environment in a different condition as wastewater. ${ }^{1-3}$ Pharmaceutical wastewater is a source of a variety of hazardous products (e.g. COD and phosphates) are typically produced in batch processes, quantities of water used for washing or extraction or washing of equipment which has negative effect on human health, so the removal of these contaminants has scientific and political interest. ${ }^{4-10}$ The removal of pharmaceutical contaminants from wastewater receives interest scientific and political attention. ${ }^{5,11-15}$ Chemical oxygen demand (COD) is a measure of the amount of organic matter which presence in water. Several studies carried out to reduce the content of COD of wastewater by using different methods of treatment. Water quality has many criteria and standards which COD test is one of the limits show the water quality where a high proportion of organic matters and low water quality. Pollutants can evaluate as COD which presence of it indicates the presence of pollutants. ${ }^{16-20}$ Phosphate, even in a very low concentration, as one of the main species responsible for eutrophication, which is a hazardous problem concerning water contamination. Because of technical and economic drawbacks, phosphate removal and recycling technologies have not yet been widely adopted. ${ }^{20-27}$ Therefore, current researchers have been focused on modification methods that more adequately address in contaminant removal from industrial wastewater. ${ }^{28,29}$

Activated carbon has a high adsorption capacity, ${ }^{30-34}$ but its cost in wastewater treatment the dispersion enough and not easy because of the dispersion of the powder. To overcome this issue and increasing the removal efficiency through entrapment activated carbon with other material ${ }^{32,36}$ such as alginate polymer which helps in adsorption process where allows polluted aqueous medium to pass through it and be in contact with activated carbon..$^{32,35-40}$ It has become one of the best effective and economics processes for treatment of wastewater, thus this method has agitated great concern during the latest years. ${ }^{41-44}$ The focus of this study was to examine the probability of entrapped activated carbon in alginate polymer for the removal of COD and phosphate from an aqueous medium. In supplement, the Freundlich and Langmuir isotherms are used to fit the data and it noted that adsorption is better explained by the Freundlich model.

\section{Experimental}

\section{Materials and reagents}

All chemicals used were of the analytical reagent grade and of the highest purity. The $\mathrm{pH}$ acidity of the aqueous solution was adjusted using $0.1 \mathrm{M} \mathrm{NaOH}$ and $0.1 \mathrm{M} \mathrm{HCl}$ solutions.

\section{Methods}

\section{Preparation of Adsorbent}

Alginate beads prepared by adding 1g of activated carbon to $2 \%$ of sodium alginate solution, stirred well. The mixture solution added drop by drop to a $5 \% \mathrm{CaCl}_{2}$ solution. The alginate beads formed taken out and washed several times to be used in the adsorption method.

\section{Preparation of standard solutions}

The standard concentrations were prepared according to Standard Methods for the Examination of Water and Wastewater, 22 editions, 2013. Required concentrations of phosphate solutions were prepared from the stock solution.

\section{Adsorption isotherm models}

Freundlich isotherm: The Freundlich isotherm ${ }^{45}$ is an empirical equation employed to describe heterogeneous adsorption surface and is given by:

$$
\operatorname{Lnqe}=1 / n \ln C e+\ln K f
$$


Where $\mathrm{K}_{\mathrm{f}}\left((\mathrm{mg} / \mathrm{g})(\mathrm{mg} / \mathrm{L})^{-1 / \mathrm{n}}\right)$ and $\mathrm{n}$ (dimensionless) are Freundlich constant related to the adsorption capacity and adsorption intensity, respectively. $\left(\mathrm{K}_{\mathrm{f}}\right)$ and $(\mathrm{n})$ evaluated by plotting $\ln \mathrm{q}_{\mathrm{e}}$ and $\ln \mathrm{C}_{\mathrm{e}}$.

\section{Langmuir isotherm model}

Langmuir isotherm model assumes monolayer coverage of adsorbate over a homogeneous surface of adsorbent. ${ }^{46}$ The Langmuir linearized model is given by the equation:

$$
C e / q e=1 /(\text { KLqmax })+C e / \text { qmax }
$$

Where $\mathrm{q}_{\mathrm{e}}(\mathrm{mg} / \mathrm{g})$ is, the mass of phosphate adsorbed per mass of adsorbent used, $\mathrm{C}_{\mathrm{e}}(\mathrm{mg} / \mathrm{L})$ is equilibrium concentration of phosphate, $\mathrm{q}_{\max }(\mathrm{mg} / \mathrm{g})$ is the maximum monolayer capacity of adsorption, and $\mathrm{K}_{\mathrm{L}}$ $(\mathrm{L} / \mathrm{mg})$ is the Langmuir constant related to binding sites affinity and adsorption energy. The plot of $\mathrm{C}_{\mathrm{e}} / \mathrm{q}_{\mathrm{e}}$ versus $\mathrm{C}_{\mathrm{e}}$ employed to generate the values of $\mathrm{q}_{\max }$ and $\mathrm{K}_{\mathrm{L}}$.

\section{Procedure of adsorption experiment}

Alginate beads with entrapped activated carbon added to a solution of chemical oxygen demand (COD) and phosphates solution containing different concentrations. Under various conditions which include: Effect of $(\mathrm{pH}$, contact time, dose, concentrations and stirring rate) and mixing the adsorbent with solution, filter solution through glass fiber filter paper (WHATMAN 1441-125) and take specific amount of filtrate and reagents carefully in test tube, then concentrations evaluated according to reference method SM4500 from $22^{\text {nd }}$ Edition of Standard Methods for the Examination of Water and Wastewater. Then the adsorption capacity and isothermal studies conducted for Freundlich and Langmuir equations.

\section{Calculation of adsorption capacity}

The efficiency of removal determined by calculation of the uptake percent (Uptake \%) and the amount of adsorbed per gram of the adsorbent $\left(\mathbf{Q}_{\mathrm{e}}\right)$, as the following equations: -

The uptake percent measured as: -

$$
\text { Uptake } \%=(C 0-C e) / C 0 * 100
$$

The uptake per gram calculated from a metal mass balance yielding: -

$$
Q e=V(C 0-C e) / m
$$

Where, $\left(\mathbf{Q}_{\mathbf{e}}\right)$ is $\mathrm{mg}$ metal ions per $\mathrm{g}$ adsorbent; $(\mathbf{V})$ is the reaction volume $(\mathrm{L}),\left(\mathbf{C}_{\mathbf{0}}\right)$ and $\left(\mathbf{C}_{\mathrm{e}}\right)$ are the initial and residual metal concentrations $(\mathrm{mg} / \mathrm{L})$, respectively, and $(\mathbf{m})$ is the number of ads sorbent $(\mathrm{g}) .^{47}$

\section{Results and discussion}

\section{Chemical oxygen demand (COD) removal}

Effect of pH: The influence of $\mathrm{pH}$ value on the amount of COD removed by entrapped activated carbon in alginate from the aqueous solution was estimated by carrying out experiments with different solution $\mathrm{pH}(1,3,5,7$ and 9) at different contact time (30, 60 and $120 \mathrm{~min}$ ), and plots of the $\mathrm{pH}$ against the percentage of COD that was removed from the solution are shown in Figure 1. The conditions used were: the initial COD concentration was $500 \mathrm{mg} \backslash \mathrm{L}$, the adsorbent dosage $30 \mathrm{~g}$ and the stirring rate fixed at $100 \mathrm{rpm}$. The optimum $\mathrm{pH}$ for the removal was 3 . The $\mathrm{pH}$ of the aqueous solution plays a decisive role in affecting COD adsorption. Similar results were reported in the scientific literature for the removal of COD. ${ }^{48,49} \mathrm{At} \mathrm{lower} \mathrm{pH}$ levels, the removal sharply increased because the positively charged functional groups of organic molecules bind through electrostatic attraction to the negatively charged of the surface of the adsorbent. On another hand, at higher $\mathrm{pH}$ the reduction in adsorption due to the increase of hindrance to organic ions diffusion because of that the abundance of $(\mathrm{OH})^{-}$ions leads to repulsion between the organic molecules and the surface of the adsorbent. ${ }^{50-55}$

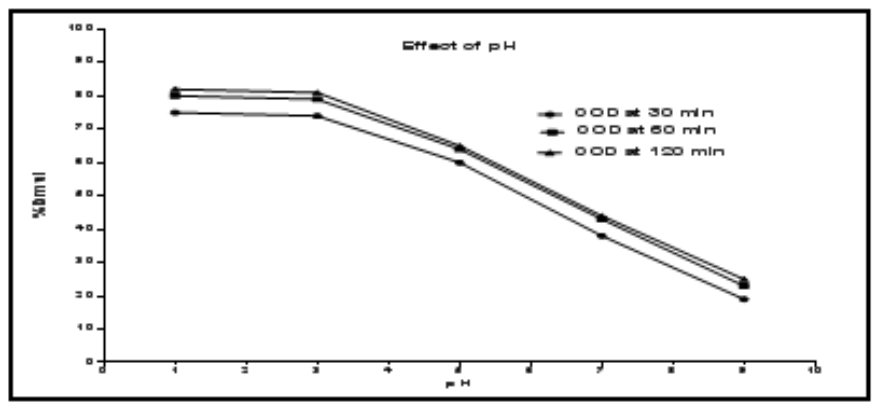

Figure I Effect of $\mathrm{pH}$ on COD removal.

Effect of contact time: The contact time is important operational factor affect removal efficiency. Figure 2 depicts COD removal as a function of contact time. From the Figure 2, it is shown that an increase in contact time increased removal efficiency (Table 2). As shown, the COD uptake by entrapped activated carbon in alginate was very rapid within the first $15 \mathrm{~min}$. After $15 \mathrm{~min}$, the uptake of COD progressively decreased with time. Similar results were reported in the scientific literature for the adsorption of COD. ${ }^{29,49-57}$ As the treatment time proceeded, the adsorbent sites had the inclination toward saturation. Equilibrium was established at $60 \mathrm{~min}$; other factors such as $\mathrm{pH}$, initial COD concentration, stirring rate, and adsorbent dose were $3,500 \mathrm{mg} \backslash \mathrm{L}, 100 \mathrm{rpm}$, and $30 \mathrm{~g}$, respectively. Increasing in time leads to increase in the contact between the solution to the larger surface area of adsorbent as there are many adsorption sites. ${ }^{58-61}$

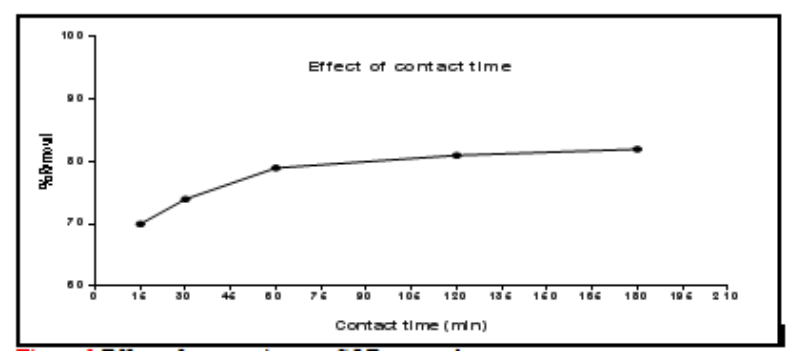

Figure 2 Effect of contact time on COD removal.

Effect of adsorbent dose: Figure $3 \mathrm{~A}$ depicts COD removal efficiency as a function of adsorbents dosage. The adsorbent doses were varied between $(10$ and 50$) \mathrm{g} / \mathrm{L}$, other operational factors $(\mathrm{pH}$, contact time, initial COD concentration and stirring rate) were $3,60 \mathrm{~min}, 500 \mathrm{mg} \backslash \mathrm{L}$, and $100 \mathrm{rpm}$. The optimum adsorbent dose for COD removal was about $30 \mathrm{~g}$, as shown in Figure 3B. Similar results were reported in the scientific literature for the adsorption of COD (Table 3) ${ }^{62,63}$ As expected, at high adsorbent does the removal increased because of the increased adsorbent surface area and the number of available adsorption sites increased. ${ }^{8,58,63,64}$ 
Effect of stirring rate: Figure 4 depicts COD removal efficiency by entrapped activated carbon in alginate as a function of stirring rate (Table 4). The stirring rate was varied between 100 and 500rpm, other operational factors $(\mathrm{pH}$, contact time, initial concentration and adsorbents dosage) were $3,60 \mathrm{~min}, 500 \mathrm{mg} \backslash \mathrm{L}$, and $30 \mathrm{~g} \backslash \mathrm{L}$, respectively. The optimum stirring rate for COD removal was 100rpm. By increasing in stirring speed resulting to increasing in COD percentage removal, was due to the fact that, increasing in stirring rate enhanced the contaminants diffusion of COD content on the surface of the adsorbent. ${ }^{63,65}$

Effect of the initial concentration: The effect of concentration of the aqueous solution on the percent COD reduction by entrapped activated carbon in alginate was studied at various initial concentrations, as shown in Figure $5 \mathrm{~A}$, other operational factors $(\mathrm{pH}$, contact time, stirring rate and adsorbents dosage) were $3,60 \mathrm{~min}, 100 \mathrm{rpm}$, and $30 \mathrm{~g} \backslash \mathrm{L}$, respectively. It can be observed that adsorption was lower at higher concentrations of COD and vice versa (Table 5). ${ }^{63}$

\section{Adsorption isotherm study on COD removal}

The sorption capacity of the adsorbent predicted and evaluated by Adsorption isotherm study (Table 5A). The adsorption equilibrium data obtained at different initial COD concentrations were described using four different isotherm models, such as the Freundlich and Langmuir equations are the most two common isotherms applications used for wastewater treatment, under predefined conditions of $\mathrm{pH}$, initial concentrations, adsorbent dose, contact time and stirring rate). ${ }^{65-70}$ The acceptability and suitability of the isotherm equation to the equilibrium data were based on the values of the correlation coefficients, $\mathrm{R}^{2}$ estimated from linear regression of the least square fit statistic on Micro Math Scientist software. Figure 5B\&C represents the adsorption isotherms for the two models. The adsorption data were fitted well with the Freundlich Isotherm model with the highest $\mathrm{R}^{2}$ in their categories as shown in Table 1 . The $n$ value $>1$ from Freundlich and maximum adsorption capacity of $38.96(\mathrm{mg} / \mathrm{g})$ from Langmuir with $\mathrm{K}_{\mathrm{L}}<1$ obtained are the indication that the adsorption is favorable on the investigated adsorbent.

\section{Phosphate removal}

Effect of pH: The influence of $\mathrm{pH}$ value on the amount of phosphate ions removed by entrapped activated carbon in alginate from the aqueous solution was estimated by carrying out experiments with different solution $\mathrm{pH}(2,4,6,8,10$ and 12) at different contact time $(30,45$ and $60 \mathrm{~min})$, and plots of the $\mathrm{pH}$ against the percentage of the phosphate ions that was removed from the solution are shown in Figure 6. The conditions used were: the initial phosphate ions concentration was $(5 \mathrm{mg} \backslash \mathrm{L})$, the adsorbent dosage $(30 \mathrm{~g})$ and the stirring rate fixed at $100 \mathrm{rpm}$. The optimum $\mathrm{pH}$ for the removal was 4 . The $\mathrm{pH}$ of the aqueous solution plays a decisive role in affecting ascorbic acid and lactose adsorption (Table 6). Similar results were reported in the scientific literature for the adsorption of. ${ }^{71-74}$ In most systems, the absorption of anions like phosphate decreases with the increase of $\mathrm{pH}$ and surface charge becomes more negative. ${ }^{75,76}$ The surface of the adsorbent became positively charged in acidic medium and negatively charged in alkaline medium. Phosphate ions are negatively charged and it appears that there are repulsion forces between ions and the negatively charged adsorbent surface in alkaline medium because of that abundance of $(\mathrm{OH})^{-}$ions and it appears that there are repulsion forces between phosphate ions and the negatively charged adsorbent surface, as shown in Figure 6A. ${ }^{72-75}$

Effect of contact time: The contact time is important operational factor affect removal efficiency. Figure 7 depicts phosphate removal as a function of contact time (Table 7). From Figure 7, it is shown that by increasing in contact time lead to increase removal efficiency. As shown, the phosphate uptake by entrapped activated carbon in alginate was very rapid within the first $15 \mathrm{~min}$. After $15 \mathrm{~min}$, the uptake of phosphate progressively decreased with time. As the treatment time proceeded, the adsorbent sites had the inclination toward saturation. Equilibrium was established at $45 \mathrm{~min}$; other factors such as $\mathrm{pH}$, initial phosphate concentrations, stirring rate, and adsorbent dose were $4,5 \mathrm{mg} \backslash \mathrm{L}, 100 \mathrm{rpm}$, and $30 \mathrm{~g}$, respectively. Similar results were reported in the scientific literature for the adsorption of phosphate. ${ }^{26,77}$ By Increasing in time leads to increase in the contact between the phosphate ions to the larger surface area available of adsorbent as there are lots of free active sites for the adsorption. ${ }^{40,58,59,63,75}$

Effect of adsorbent dose: Figure 8A depicts phosphate removal efficiency as a function of adsorbents dosage. The adsorbent doses were varied between 10 and $50 \mathrm{~g} / \mathrm{L}$, other operational factors $(\mathrm{pH}$, contact time, initial phosphate concentrations and stirring rate) were 4, 45min, $5 \mathrm{mg} \backslash \mathrm{L}$, and $100 \mathrm{rpm}$, respectively. The optimum adsorbent dose for phosphate ions removal was found to be about 25g (Figure $8 \mathrm{~B})$. As expected, at high adsorbent does the removal increased because of the increased adsorbent surface area and the number of available adsorption sites increased (Table 8) ${ }^{80}$

Effect of stirring rate: Figure 9 depicts phosphate removal efficiency by entrapped activated carbon in alginate as a function of stirring rate. The stirring rate was varied between 100 and 500rpm, other operational factors $(\mathrm{pH}$, contact time, initial concentration, and adsorbents dosage) were $4,45 \mathrm{~min}, 5 \mathrm{mg} \backslash \mathrm{L}$, and $30 \mathrm{~g} \backslash \mathrm{L}$, respectively. The optimum stirring rate for phosphate ions removal was found to be $100(\mathrm{rpm})$. Similar results were reported in the scientific literature for the adsorption of phosphate. ${ }^{78,79}$ Increasing in stirring rate, enhanced the phosphate ions diffusion to the surface of the adsorbent (Table 9).

Effect of the initial concentration: The effect of concentration of the aqueous solution on the percent phosphate reduction by entrapped activated carbon in alginate was studied at various initial concentrations, as shown in Figure 10A, other operational factors ( $\mathrm{pH}$, contact time, stirring rate and adsorbents dosage) were 4, 45 min, $100 \mathrm{rpm}$, and $30 \mathrm{~g} \backslash \mathrm{L}$, respectively (Table $10 \mathrm{~A}$ ). At the beginning of the adsorption process, the removal efficiency was higher because of the great number of available adsorption active sites of adsorbate molecules but it decreased with time gradually due to the saturation and diminished of this sites, also caused a reduction in removal ratio.

\section{Adsorption isotherm study for phosphate removal}

The sorption capacity of the adsorbent predicted and evaluated by Adsorption isotherm study (Table 10B). The adsorption equilibrium data obtained at different initial phosphate concentrations were described using two different isotherm models, such as the Freundlich and Langmuir equations are the most two common isotherms applications used for wastewater treatment, under predefined conditions of $\mathrm{pH}$, initial concentrations, adsorbent dose, contact time and stirring rate). The acceptability and suitability of the isotherm equation to the equilibrium data were based on the values of the correlation coefficients, $\mathrm{R}^{2}$ estimated from linear regression of the least square fit statistic on Micro Math Scientist software. Figures $10 \mathrm{~b} \& \mathrm{c}$ represents the adsorption isotherms for the four models. The adsorption data were fitted well with the Freundlich Isotherm model with the highest $\mathrm{R}^{2}$ in their categories]. The $\mathrm{n}$ value $>1$ from Freundlich and maximum adsorption capacity of $0.34 \mathrm{mg} / \mathrm{g}$ from Langmuir with $\mathrm{K}_{\mathrm{L}}<1$ obtained are the indication that the adsorption is favorable on the investigated adsorbent. ${ }^{81,82}$ 


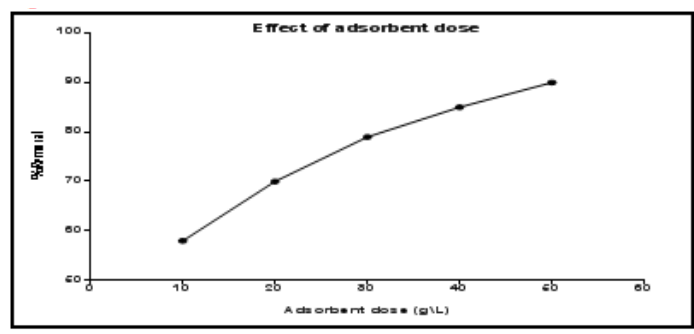

Figure 3A Effect of adsorbent dose on COD removal.

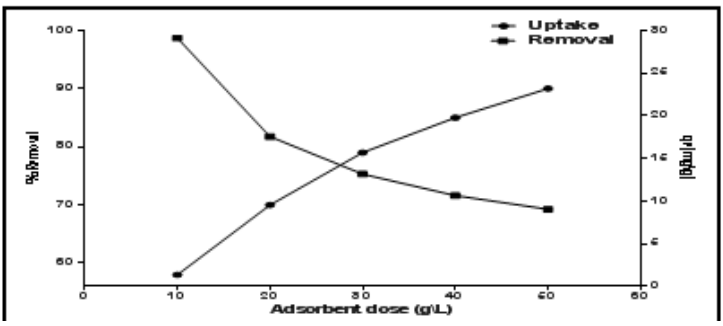

Figure 3B The optimum effective dose for COD removal.

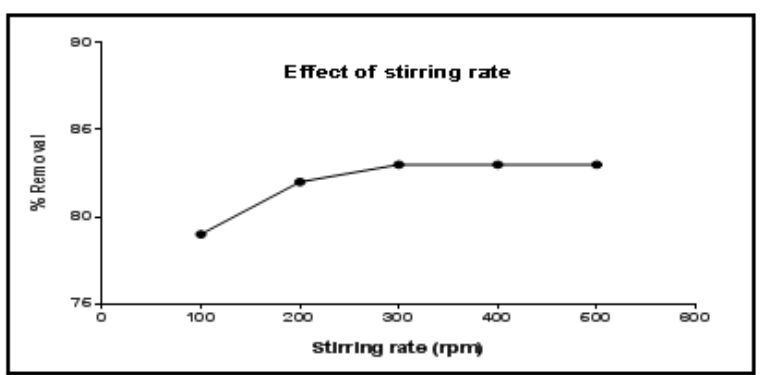

Figure 4 Effect of stirring rate on COD removal.

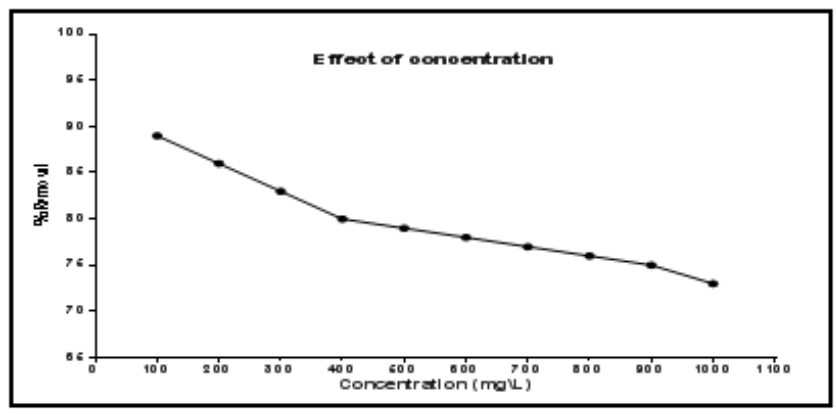

Figure 5A Effect of initial concentration on COD removal.

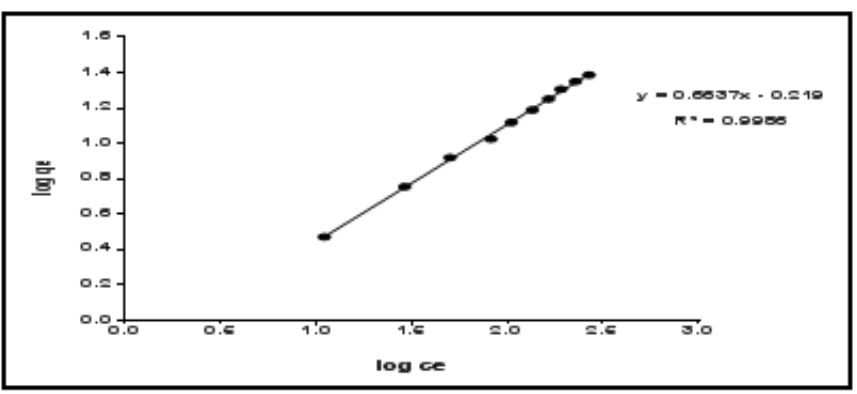

Figure 5B Freundlich adsorption isotherm for COD contributing component.

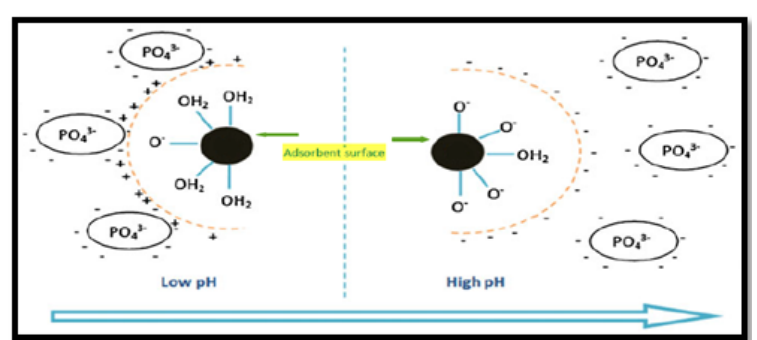

Figure 6A Phosphate sorption by on (AG-AC) under various $\mathrm{pH}$ conditions.

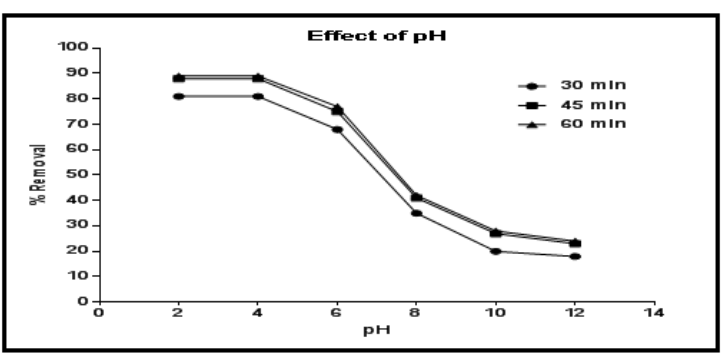

Figure 6B Effect of $\mathrm{pH}$ on phosphate removal.

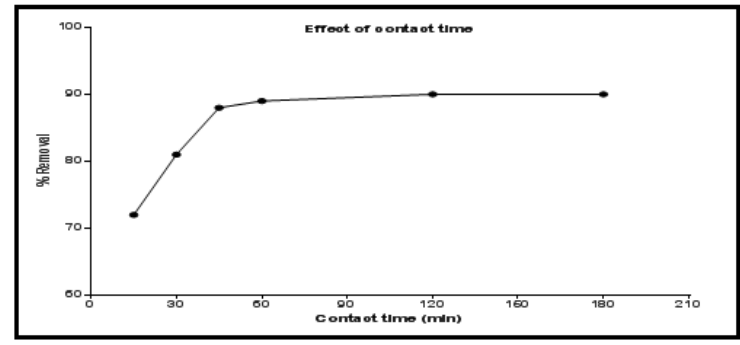

Figure 7 Effect of contact time on phosphate removal.

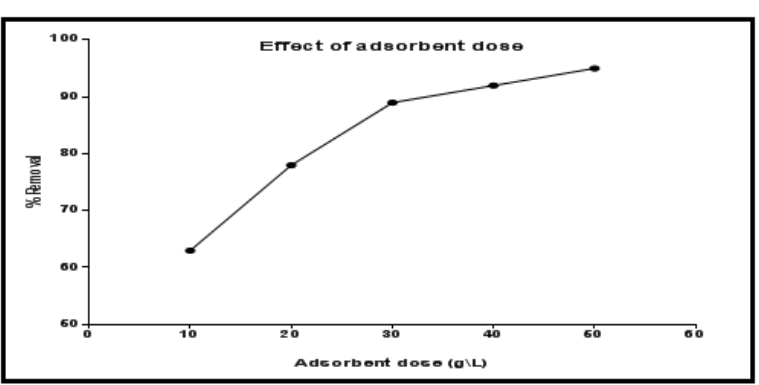

Figure 8A Effect of adsorbent dose on phosphate removal.

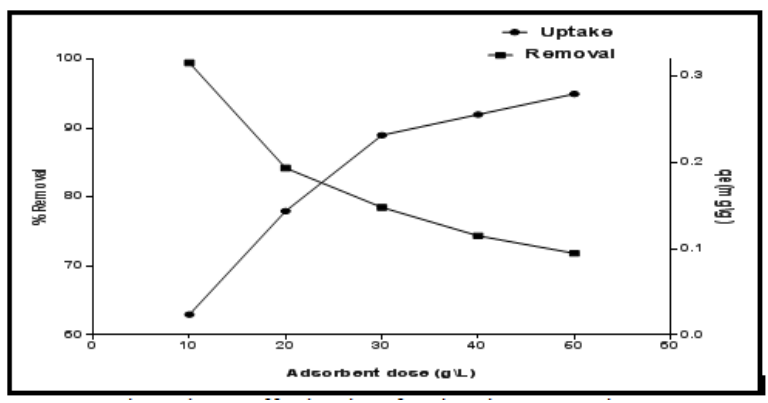

Figure 8B The optimum effective dose for phosphate removal. 


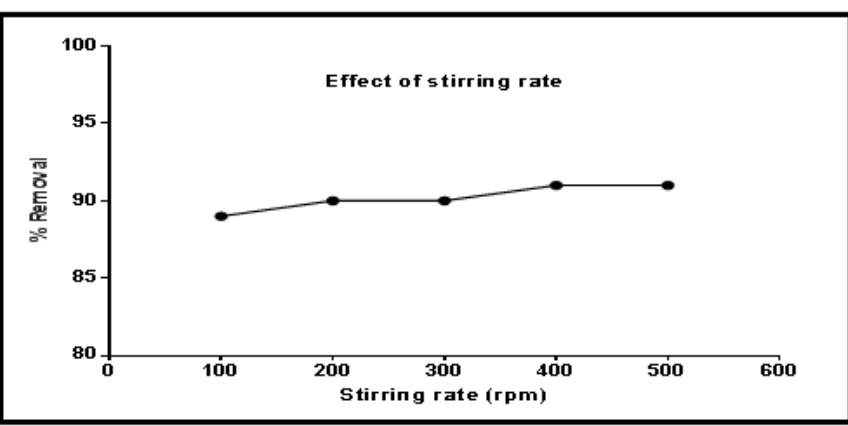

Figure 9 Effect of stirring rate on phosphate removal.

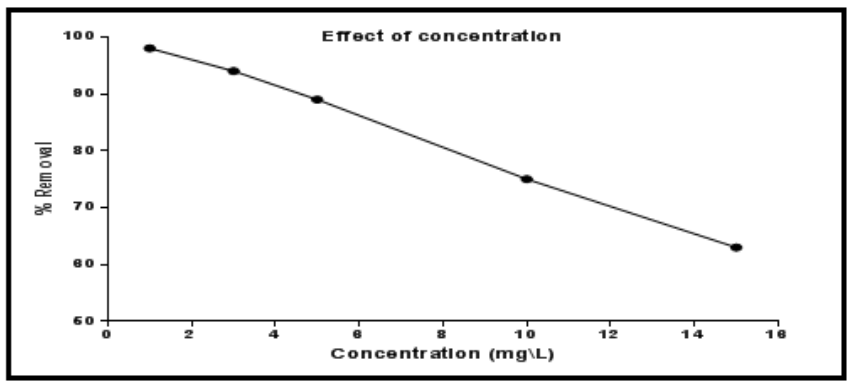

Figure IOA Effect of initial concentration on phosphate removal.

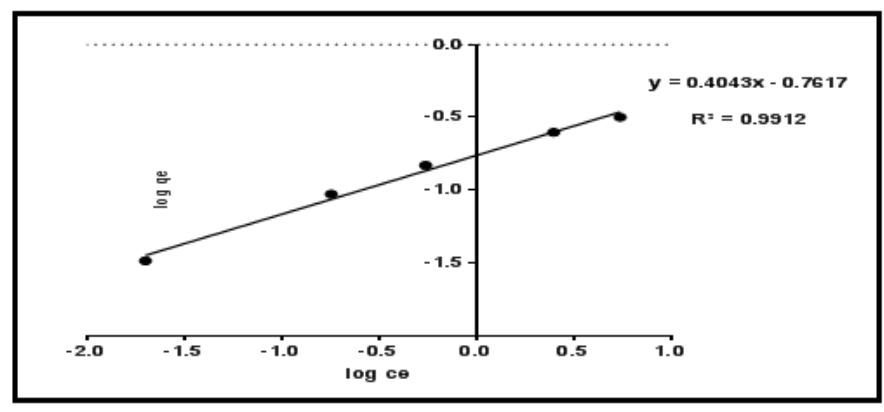

Figure IOB Freundlich adsorption isotherm for phosphates contributing component.

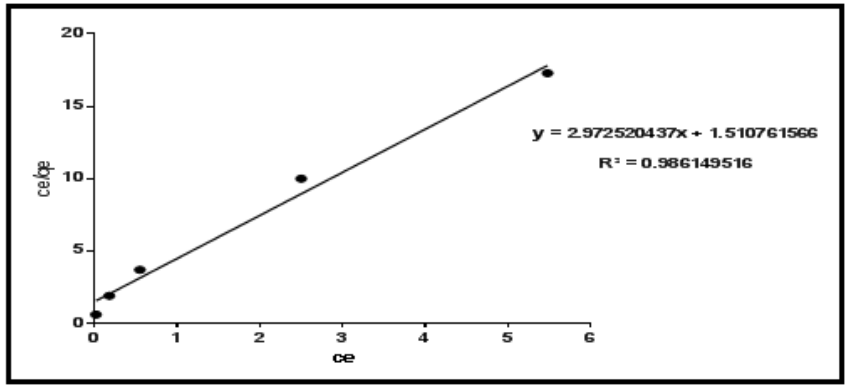

Figure I0C Langmuir adsorption isotherm for phosphates contributing component.

Table I Effect of $\mathrm{pH}$ on COD removal at different times

\begin{tabular}{|c|c|c|c|c|c|c|}
\hline pH & 30 (min) & Removal \% & $60(\mathrm{~min})$ & Removal \% & $120(\min )$ & Removal \% \\
\hline I & 123 & 75 & 99 & 80 & 82 & 82 \\
\hline 3 & 129 & 74 & 105 & 79 & 81 & 81 \\
\hline 5 & 202 & 60 & $|8|$ & 64 & 65 & 65 \\
\hline 7 & 309 & 38 & 284 & 43 & 44 & 44 \\
\hline 9 & 403 & 19 & 387 & 23 & 25 & 25 \\
\hline
\end{tabular}

Table 2 Effect of contact time on COD removal

\begin{tabular}{llll}
\hline Time $(\mathbf{m i n})$ & Before $(\mathbf{m g} / \mathbf{L})$ & After $(\mathbf{m g} / \mathbf{L})$ & Removal \% \\
15 & 500 & 148 & 70 \\
30 & 500 & 129 & 74 \\
60 & 500 & 105 & 79 \\
120 & 500 & 95 & 81 \\
180 & 500 & 93 & 82 \\
\hline
\end{tabular}

Table 3 Effect of adsorbent dose on COD removal

\begin{tabular}{llll}
\hline Dose $(\mathbf{g} / \mathbf{L})$ & Before $(\mathbf{m g} / \mathbf{L})$ & After $(\mathbf{m g} / \mathbf{L})$ & Removal \% \\
10 & 500 & 209 & 58 \\
20 & 500 & 149 & 70 \\
30 & 500 & 105 & 79 \\
40 & 500 & 74 & 85 \\
50 & 500 & 48 & 90 \\
\hline
\end{tabular}


Table 4 Effect of stirring rate on COD removal

\begin{tabular}{llll}
\hline Stirring rate $(\mathbf{r p m})$ & Before $(\mathbf{m g} / \mathbf{L})$ & After $(\mathbf{m g} / \mathbf{L})$ & Removal \% \\
100 & 500 & 105 & 79 \\
200 & 500 & 91 & 82 \\
300 & 500 & 85 & 83 \\
400 & 500 & 83 & 83 \\
500 & 500 & 85 & 83 \\
\hline
\end{tabular}

Table 5A Effect of initial concentration on COD removal

\begin{tabular}{lll} 
Initial Concentration (mg/L) & Final Concentration $(\mathbf{m g} / \mathbf{L})$ & Removal \% \\
100 & 11 & 89 \\
200 & 29 & 86 \\
300 & 50 & 83 \\
400 & 82 & 80 \\
500 & 105 & 79 \\
600 & 135 & 78 \\
700 & 164 & 77 \\
800 & 191 & 76 \\
900 & 227 & 75 \\
1000 & 267 & 73 \\
\hline
\end{tabular}

Table 5B Isotherm parameters for the adsorption of COD

\begin{tabular}{lll}
\hline Isotherm name & Parameters & Values \\
Freundlich & $\mathrm{K}_{\mathrm{F}}\left(\mathrm{mg} / \mathrm{g}\left(\mathrm{mg} / \mathrm{L}^{-1 / \mathrm{n}}\right)\right.$ & $\mathrm{I}$ \\
& $\mathrm{n}$ & $\mathrm{I}$ \\
& $\mathrm{R}^{2}$ & $0.5 \mathrm{I}$ \\
\hline Langmuir & $\mathrm{Qmax}(\mathrm{mg} / \mathrm{g})$ & 38.96 \\
& $\mathrm{~K}_{\mathrm{L}}(\mathrm{L} / \mathrm{mg})$ & 0.006 \\
\hline & $\mathrm{R}^{2}$ & 0.9185 \\
\hline
\end{tabular}

Table 6 Effect of $\mathrm{pH}$ on phosphate removal at different times

\begin{tabular}{lllllll}
\hline $\mathrm{pH}$ & $\mathbf{3 0}(\mathrm{min})$ & Removal \% & $\mathbf{4 5}(\mathrm{min})$ & Removal \% & $\begin{array}{l}\mathbf{6 0} \\
(\mathbf{m i n})\end{array}$ & Removal \% \\
2 & 0.93 & 81 & 0.58 & 88 & 0.53 & 89 \\
4 & 0.95 & 81 & 0.59 & 88 & 0.55 & 89 \\
6 & 1.58 & 68 & 1.25 & 75 & 1.15 & 77 \\
8 & 3.26 & 35 & 2.95 & 41 & 2.91 & 42 \\
10 & 3.99 & 20 & 3.65 & 27 & 3.59 & 28 \\
12 & 4.11 & 18 & 3.85 & 23 & 3.79 & 24 \\
\hline
\end{tabular}


Table 7 Effect of contact time on phosphate removal

\begin{tabular}{llll}
\hline Time $(\mathbf{m i n})$ & Before $(\mathbf{m g} / \mathbf{L})$ & After $(\mathbf{m g} / \mathbf{L})$ & Removal \% \\
15 & 5 & 1.39 & 72 \\
30 & 5 & 0.95 & 81 \\
45 & 5 & 0.59 & 88 \\
60 & 5 & 0.55 & 89 \\
120 & 5 & 0.51 & 90 \\
180 & 5 & 0.49 & 90 \\
\hline
\end{tabular}

Table 8 Effect of adsorbent dose on phosphate removal

\begin{tabular}{llll}
\hline Dose $(\mathbf{g} / \mathbf{L})$ & Before $(\mathrm{mg} / \mathbf{L})$ & After $(\mathrm{mg} / \mathbf{L})$ & Removal \% \\
10 & 5 & 1.48 & 63 \\
20 & 5 & 1.12 & 78 \\
30 & 5 & 0.55 & 89 \\
40 & 5 & 0.39 & 92 \\
50 & 5 & 0.25 & 95 \\
\hline
\end{tabular}

Table 9 Effect of stirring rate on phosphate removal

\begin{tabular}{llll}
\hline Stirring rate $(\mathbf{r p m})$ & Before $(\mathbf{m g} / \mathbf{L})$ & After $(\mathbf{m g} / \mathbf{L})$ & Removal \% \\
100 & 5 & 0.55 & 89 \\
200 & 5 & 0.49 & 90 \\
300 & 5 & 0.48 & 90 \\
400 & 5 & 0.47 & 91 \\
500 & 5 & 0.51 & 90 \\
\hline
\end{tabular}

Table I0A Effect of initial concentration on phosphate removal

\begin{tabular}{lll}
\hline Initial concentration $(\mathbf{m g} / \mathbf{L})$ & Final concentration $(\mathbf{m g} / \mathbf{L})$ & Removal \% \\
I & 0.02 & 98 \\
3 & 0.18 & 94 \\
5 & 0.55 & 89 \\
10 & 2.5 & 75 \\
\hline 5
\end{tabular}

Table IOB Isotherm parameters for the adsorption of phosphate on (AG-AC)

\begin{tabular}{lll}
\hline Isotherm name & Parameters & Values \\
Freundlich & $\mathrm{K}_{\mathrm{F}}\left(\mathrm{mg} / \mathrm{g}\left(\mathrm{mg} / \mathrm{L}^{-1 / \mathrm{n}}\right)\right.$ & 5.78 \\
& $\mathrm{n}$ & 2.47 \\
\hline Langmuir & $\mathrm{R}^{2}$ & 0.9912 \\
& $\mathrm{Qmax}(\mathrm{mg} / \mathrm{g})$ & 0.34 \\
& $\mathrm{~K}_{\mathrm{L}}(\mathrm{L} / \mathrm{mg})$ & 0.508 \\
\hline
\end{tabular}




\section{Conclusion}

In this study, the results showed that entrapped activated carbon in alginate polymer is capable of COD and phosphate removal from aqueous solution. Various operating parameters on phosphate and COD removal efficiency investigated and optimized. Removal affected by the experimental parameters such as contact time, dosage, $\mathrm{pH}$, stirring rate, initial concentration. The entrapped activated carbon in alginate polymer be a cost-effective alternative and can lead to success in wastewater treatment and produce high-quality treated effluent.

\section{Acknowledgments}

None.

\section{Conflicts of interest}

Author declares there is no conflict of interest towards the manuscript.

\section{References}

1. Henze M, Harremoes P, Arvin E, et al. Wastewater treatment: biological and chemical processes. USA: Springer Science \& Business Media.

2. Malik L Hami, Al-Hashimi MA, Al-Doori MM. Effect of activated carbon on BOD and COD removal in a dissolved air flotation unit treating refinery wastewater. Desalination. 2007;216(1-3):116-122.

3. Spellman FR. Handbook of water and wastewater treatment plant operations. $3^{\text {rd }}$ edn. USA: CRC Press; 2013.

4. LaPara TM, Nakatsu CH, Pantea LM, et al. Stability of the bacterial communities supported by a seven-stage biological process treating pharmaceutical wastewater as revealed by PCR-DGGE. Water Res 2002;36(3):638-646.

5. Akmehmet Balcioğlu I1, Otker M. Treatment of pharmaceutical wastewater containing antibiotics by $\mathrm{O} 3$ and $\mathrm{O} 3 / \mathrm{H} 2 \mathrm{O} 2$ processes. Chemosphere. 2003;50(1):85-95.

6. Chelliapan S, Wilby T, Sallis PJ. Performance of an up-flow anaerobic stage reactor (UASR) in the treatment of pharmaceutical wastewater containing macrolide antibiotics. Water Res. 2006;40(3):507-516.

7. Sirtori C, Zapata A, Oller I, et al. Decontamination industrial pharmaceutical wastewater by combining solar photo-Fenton and biological treatment. Water Res. 2009;43(3):661-668.

8. Samiksha Gaikwad SJ. Reduction of Chemical Oxygen Demand by using coconut shell activated carbon and sugarcane bagasse fly ash. International Journal of Science and Research. 2013;4(7):642-645.

9. Catarina L Amorim, Irina S Moreira, Ana R Ribeiro, et al. Treatment of a simulated wastewater amended with a chiral pharmaceuticals mixture by an aerobic granular sludge sequencing batch reactor. International Biodeterioration \& Biodegradation. 2016;115:277-285.

10. Ma K, Qin Z, Zhao Z, et al. Toxicity evaluation of wastewater collected at different treatment stages from a pharmaceutical industrial park wastewater treatment plant. Chemosphere. 2016;158:163-70.

11. El-Gohary FA, Abou-Elela SI, Aly HI. Evaluation of biological technologies for wastewater treatment in the pharmaceutical industry. Water Science and Technology. 1995;32(11):13-20.

12. Torres LG, Jaimes J, Mijaylova P, et al. Coagulation-flocculation pretreatment of high-load chemical-pharmaceutical industry wastewater: mixing aspects. Water science and technology 1997;36(2-3):255-262.

13. Nakada N, Tanishima T, Shinohara H, et al. Pharmaceutical chemicals and endocrine disrupters in municipal wastewater in Tokyo and their removal during activated sludge treatment. Water Res. 2006;40(17):3297-3303.
14. Gadipelly C, Antía Pérez-González, Ganapati D, et al. Pharmaceutical industry wastewater: review of the technologies for water treatment and reuse. Ind Eng Chem Res. 2014;53(29):11571-11592.

15. Mestre AS, Ricardo A Pires, Aroso I, et al. Activated carbons prepared from industrial pre-treated cork: Sustainable adsorbents for pharmaceutical compounds removal. Chemical Engineering Journal. 2014;253:408-417.

16. Zhang Z, Yuan Y, Fang Y, et al. Preparation of photocatalytic nano$\mathrm{ZnO} / \mathrm{TiO}$, film and application for determination of chemical oxygen demand. Talanta. 2007;73(3):523-528.

17. Zheng Q, Zhou B, Bai J, et al. Self-Organized TiO2 Nanotube Array Sensor for the Determination of Chemical Oxygen Demand. Advanced Materials. 2008;20(5):1044-1049.

18. Ademiluyi F, Amadi S, Amakama NJ. Adsorption and Treatment of Organic Contaminants using Activated Carbon from Waste Nigerian Bamboo. J Appl Sci Environ Manage. 2009;13(3):39-47.

19. Dubber D, Gray NF. Replacement of chemical oxygen demand (COD) with total organic carbon (TOC) for monitoring wastewater treatment performance to minimize disposal of toxic analytical waste. $J$ Environ Sci Health A Tox Hazard Subst Environ Eng. 2010;45(12):1595-1600.

20. Syafalni S, Abustan I, Dahlan I, et al. Treatment of dye wastewater using granular activated carbon and zeolite filter. Modern Applied Science. 2012;6(2):37.

21. de-Bashan LE, Bashan Y. Recent advances in removing phosphorus from wastewater and its future use as fertilizer (1997-2003). Water Res. 2004;38(19):4222-4246.

22. Karapinar N, Hoffmann E, Hahn HH. Magnetite seeded precipitation of phosphate. Water Res. 2004;38(13):3059-3066.

23. Silke Krögera, Robin J, Law L. Sensing the sea. Trends in biotechnology. 2005;23(5):250-256.

24. Eskandarpour A, Sassa K, Bando Y, et al. Magnetic removal of phosphate from wastewater using schwertmannite. Materials Transactions. 2006b;47(7):1832.

25. Cleary JC, Slater D. Diamond. Analysis of phosphate in wastewater using an autonomous microfluidics-based analyser. World Academy of Science, Engineering and Technology, Ireland.

26. Zhong-liang SHI, Fu-mei LIU, Shu-hua YAO. Adsorptive removal of phosphate from aqueous solutions using activated carbon loaded with Fe (III) oxide. New carbon materials. 2011;26(4):299-306.

27. Liu Y, Sheng X, Dong Y. Removal of high-concentration phosphate by calcite: effect of sulfate and pH. Desalination. 2012;289:66-71.

28. Washington E. "Primer for Municipal Waste water Treatment Systems." Document no. EPA 832-R-04-001. 2004.

29. Murali K, Karuppiah P, Nithish M, et al. COD Reduction Using Low Cost Biosorbent as Part of Cleaner Production. International Journal of Scientific and Research Publication.s 2013a;3(7):1-3.

30. Luiz CA Oliveira, Rachel VRA Rios, José D Fabris, et al. Activated carbon/iron oxide magnetic composites for the adsorption of contaminants in water. Carbon. 2002;40(12):2177-2183.

31. Gonzalez-Serrano E, Cordero T, Rodriguez-Mirasol T, et al. Removal of water pollutants with activated carbons prepared from $\mathrm{H} 3$ PO 4 activation of lignin from kraft black liquors. Water Research. 2004;38(13):3043-3050.

32. Lin YB, Fugetsu B, Terui N, et al. Removal of organic compounds by alginate gel beads with entrapped activated carbon. $J$ Hazard Mater. 2005;120(1-3):237-241.

33. Snyder SA, Adham S, Redding AM, et al. Role of membranes and activated carbon in the removal of endocrine disruptors and pharmaceuticals. Desalination. 2007;202(1-3):156-181. 
34. Yin CY, Aroua MK, Daud WMAW. Review of modifications of activated carbon for enhancing contaminant uptakes from aqueous solutions. Separation and Purification Technology. 2007;52(3):403-415.

35. Sumana Siripattanakul-Ratpukdi, Thitiporn Tongkliang. Municipal wastewater treatment using barium alginate entrapped activated sludge: Adjustment of utilization conditions. IJCEA. 2012;3(5):328-332.

36. Christopher B Hill, Eakalak Khan. A comparative study of immobilized nitrifying and co-immobilized nitrifying and denitrifying bacteria for ammonia removal from sludge digester supernatant. Water, Air, and Soil Pollution. 2008;195(23):23-33.

37. Brachkova MI, Duarte MA, Pinto JF. Preservation of viability and antibacterial activity of Lactobacillus spp. in calcium alginate beads. Eur $J$ Pharm Sci. 2010;41(5):589-596.

38. Sumana Siripattanakul, Eakalak Khan. 2010.

39. Bezbaruah A, Almeelbi TB, Quamme M, et al. Calcium-alginate entrapped nanoscale zero-valent iron (nzvi). PATENTSCOPE, USA.

40. Soha A Abdel-Gawad, Amin M Baraka, Maha M El-Shafei, et al. Effects of nano zero valent iron and entrapped nano zero valent iron in alginate polymer on poly aromatic hydrocarbons removal. Journal of Environment \& Biotechnology Research. 2016;5(1):18-28.

41. Ali I, Gupta V. Advances in water treatment by adsorption technology. Nature protocols. 2007;1:2661-2667.

42. Worch E. Adsorption technology in water treatment: fundamentals, processes, and modeling. Green Sciences, Walter de Gruyter 2012.

43. Samuel D. Faust and Osman M. Aly. 2013. Adsorption processes for water treatment. Elsevier, USA.

44. Rashed MN. Adsorption technique for the removal of organic pollutants from water and wastewater. , UK: INTECH Open Access Publisher; 2013.

45. Freundlich H. Over the adsorption in solution. J Phys Chem. 1906;57:e470.

46. Irving Langmuir. The adsorption of gases on plane surfaces of glass, mica and platinum. J Am Chem Soc. 1918;40(9):1361-1403.

47. Gadd GM, Gadd G. Accumulation of metals by microorganisms and algae. Biotechnology. 1988;6:401-433.

48. Rani Devi, Dahiya RP. COD and BOD removal from domestic wastewater generated in decentralised sectors. Bioresour Technol. 2008;99(2):344-349.

49. Lokeshwari N, Joshi K. Low cost adsorbent for reducing organic components. Jr. of Industrial Pollution Control. 2014.30(1):53-58.

50. Manka J, Rebhun M, Mandelbaum A, et al. Characterization of organics in secondary effluents. Environ Sci Technol. 1974;8(12):1017-1020.

51. Liskowitz J, Chan P, Trattner R, et al. Lechate treatment utilizing fly ashclay mixture in: Proc. of National conference on hazardous and toxic waste management. New Jersey. 1980;2:515-544.

52. Mall I, Mishra N, Mishra I. Removal of Organic Matters From Sugar Mill Effluent Using Bagasse Fly-Ash Activated Carbon. Research and Industry. 1994;39:115-119.

53. Das CP, Patnaik LN. Use of industrial waste for reduction of COD from paper mill effluent. Indian J Environ Health. 2001;43(1):21-27.

54. Kunwar P Singh, Dinesh Mohan, Sarita Sinha, et al. Color Remova from Wastewater Using Low-Cost Activated Carbon Derived from Agricultural Waste Material. Ind Eng Chem Res. 2003;42(9):19651976.

55. Baisali Sarkar, Chakrabarti PP, Vijaykumar A, et al. Wastewater treatment in dairy industries-possibility of reuse. Desalination. 2006;195(1-3):141-152.
56. Rani Devi, Dahiya RP. COD and BOD removal from domestic wastewater generated in decentralised sectors. Bioresour Technol. 2008;99(2):344-349.

57. Nevine Kamal Amin. Removal of reactive dye from aqueous solutions by adsorption onto activated carbons prepared from sugarcane bagasse pith. Desalination. 2008;223(1-3):152-161.

58. Sunil J Kulkarni, Suhas V Patil, Ravi W, et al. Studies on Adsorption for Phenol Removal by using Activated Carbon in Batch and Fluidized Bed Adsorption. International Conference On Current Trends In Technology. 2011;8-10:382.

59. Rakholiya VV, Puranik SA. COD reduction using modifying industrial effluent treatment flowsheet and low cost adsorbent as a part of cleaner production. Advances in Applied Science Research. 2012;3(3):1279-1291

60. Eulalio Campos-González,a Bernardo A. Frontana-Uribe,b Ruben Vasquez-Medrano, et al. 2014. Advanced electrochemical oxidation of Methyl Parathion at boron-doped diamond electrodes. J Mex Chem Soc 2014;58(3):315-321.

61. Sivakumar D, Rajaganapathy J, Anand R, et al. TOC and COD removal from municipal solid waste leachate using Electrocoagulation method. Journal of Chemical and Pharmaceutical Sciences. 2015;8(4):745-749.

62. Amuda OS, Ibrahim AO. Industrial wastewater treatment using natural material as adsorbent. African Journal of Biotechnology. 2006;5(16):1483-1487.

63. Devi R, Singh V, Kumar A. COD and BOD reduction from coffee processing wastewater using Avacado peel carbon. Bioresour Technol. 2008;99(6):1853-1860

64. Garg KK, Rawat P, Prasad B. Removal of Cr (VI) and COD from Electroplating Wastewater by Corncob Based Activated Carbon. Int J Water and Wastewater Treatment. 2015;1(1):1-9.

65. Bernard E, Jimoh A, Odigure JO. Heavy metals removal from industrial wastewater by activated carbon prepared from coconut shell. Research Journal of Chemical Sciences. 2013;3(8):3-9.

66. Ho YS, Chiang CC. Sorption studies of acid dye by mixed sorbents Adsorption. 2001;7(2):139-147.

67. Foo KY, Hameed BH. Insights into the modeling of adsorption isotherm systems. Chemical Engineering Journal. 2010;156(1):2-10.

68. Adeogun AI, Balakrishnan RB. Kinetics, isothermal and thermodynamics studies of electrocoagulation removal of basic dye rhodamine B from aqueous solution using steel electrodes. Applied Water Science. 2017;7(4):1711-1723.

69. Akinhanmi Temilade Fola, Adeogun Abideen Idowu, Adegbuyi Adetutu. 2016. Removal of $\mathrm{Cu} 2+$ from aqueous solution by adsorption onto quail eggshell: Kinetic and isothermal studies. Journal of Environment and Biotechnology Research. 5, Number 1, 2016, pp. 1-9.

70. Adeogun A Idowu, Omeike Sunday, Kareem Sarafadeen Olateju. Removal of Mn (II) from aqueous solution by Irvingia gabonensis immobilized Aspergillus sp. TU-GM14: Isothermal, kinetics and thermodynamic studies. Journal of Environment and Biotechnology Research. 2016;3(1):1-11

71. H Soner Altundoğan, Fikret Tümen. Removal of phosphates from aqueous solutions by using bauxite. I: Effect of $\mathrm{pH}$ on the adsorption of various phosphates. Journal of Chemical Technology and Biotechnology. $2002 ; 77(1): 77-85$.

72. Yao Y, Gao B, Inyang M, et al. Removal of phosphate from aqueous solution by biochar derived from anaerobically digested sugar beet tailings. J Hazard Mater. 2011;190(1-3):501-507.

73. Mohamed E, Selim A, Selim M, et al. Modeling and Optimizations of Phosphate Removal from Aqueous Solutions using Synthetic Zeolite $\mathrm{Na}-\mathrm{A}$. Journal of Materials Science and Chemical Engineering. 2015;3(9):15. 
74. Subha E, Sasikala S, Muthuraman G. Removal of Phosphate from wastewater using natural adsorbents. International Journal of ChemTech Research. 2015;1(7):3095-3099.

75. Zhou A, Tang H, Wang D. Phosphorus adsorption on natural sediments: modeling and effects of $\mathrm{pH}$ and sediment composition. Water Res. 2005;39(7):1245-1254.

76. Eskandarpour A, Sassa K, Bando Y, et al. Magnetic removal of phosphate from wastewater using schwertmannite. Materials Transactions. 2006a;47(7):1832-1837.

77. Zhang L, Wan L, Chang N, et al. Removal of phosphate from water by activated carbon fiber loaded with lanthanum oxide. J Hazard Mater. 2011;190(1-3):848-855.

78. Karaca S1, Gürses A, Ejder M, et al. Açıkyıldız. 2006. Adsorptive removal of phosphate from aqueous solutions using raw and calcinated dolomite. J Hazard Mater. 2006;128(2-3):273-279.
79. Mahmood Z, Nasir S, Jamil N, et al. Adsorption studies of phosphate ions on alginate-calcium carbonate composite beads. African Journal of Environmental Science and Technology.2015;9(3):274-281.

80. Samorn Hirunpraditkoon, Nathaporn Tunthong, Anotai Ruangchai, et al. Adsorption capacities of activated carbons prepared from bamboo by $\mathrm{KOH}$ activation. World Academy of Science, Engineering and Technology 54:647-651.

81. Sumana Siripattanakul, Eakalak Khan. 2010.

82. Fundamentals and applications of entrapped cell bioaugmentation for contaminant removal. Emerging Environmental Technologies. Springer, USA; 2010. p. 147-169. 